\title{
The enlightenment of the drop in oil prices and the ruble crisis
}

\author{
Siyuan Gong*, Yan Zhou \\ Nanjing University of Science and Technology , China \\ *Corresponding author: Siyuan Gong 275128740@qq.com
}

\begin{abstract}
From the July 2014, the international crude oil price has been continuously declined. The exchange rate of ruble has been depreciated. The crisis of ruble happened because the Russia's economy dependeds on oil export highly. According to the research, The RMB exchange rate is a one-way cause-and-effect relationship with oil price, Russia and China are at the same stage in the process of establishing a market economy, and the Russian ruble crisis in the country is worth our learning.
\end{abstract}

Key words: The ruble crisis; oil price; Russian economy

\section{Introduction}

The exchange which had been 33 of rubles to one American dollar at the beginning of 2014, but, at the end of this year we need to use more than 50 ruble for one dollar. The devaluation of the ruble was more than $40 \%$. At the peak of the year, the exchange rate of the ruble against the dollar fell by about 55 percent. The worsening economic environment has also caused outflows of funds in Russia. In 2014, Russia's outflow of capital was in excess of \$120 billion. Huge capital outflows further exacerbated the financial crisis in Russia.

The fall of oil prices directly reduced the foreign exchange income of the Russian government. In 2015, Russia's federal revenue reduced by about 1 trillion rubles, and the reduction in fiscal and the foreign exchange income weakened the government's control over the crisis.

In the adverse economic environment, the living standard of the Russian people has also been declining. According to relevant statistics, during the crisis, the average salary of ordinary Russian workers fell by $27 \%$, and the average monthly salary had fallen to less than $\$ 600$.

Li jianmin (2015) ${ }^{1}$ elaborated on the predicament of the current Russian economy, focusing on the fragility of the ruble, which was the fundamental cause of the economic weakness of the Russian economy. The external sanctions of the western countries were the trigger of the problem, Su junhe(2015) ${ }^{2}$ analyzed the relationship between the Chinese economy, the RMB 
exchange rate and the international oil price, concluded that the RMB exchange rate is in the same direction as the international oil price. However, very few people are concerned about the direct relationship between oil prices and the ruble. This article will build a bridge between the price of oil and the ruble rate.

\section{2、 Empirical study on ruble and oil price}

In order to learn the relationship between the oil price and ruble, I choose the following variables and use the multiple linear regressions.

Table 1: variable description

\begin{tabular}{llll}
\hline oil & The price of Russian oil exports & exchange & Exchange rate of ruble against us dollar \\
M2 & Broad money & bsccy & Russian basic currency \\
reserve & Russian foreign exchange reserve & deposit & Russian benchmark one-year deposit \\
income & Income of Russian government & RTS & RTS index \\
cpi & Russian Consumer price index & net export & Russian net export \\
ppi & Russian producer price index & investment & Russian fix asset investment \\
\hline
\end{tabular}

\subsection{Data}

Table 2: Summary statistics

\begin{tabular}{lllllll}
\hline variable & $\mathrm{N}$ & Mean & median & Standard deviation & minimum & maximum \\
exchange & 198 & 3.506220 & 3.413412 & 0.291148 & 3.154683 & 4.319783 \\
Oil & 198 & 5.947061 & 5.972282 & 0.563277 & 4.750136 & 6.788746 \\
reserve & 198 & 12.39667 & 12.87171 & 0.929153 & 10.25221 & 13.29895 \\
income & 198 & 6.353999 & 6.513822 & 0.711864 & 4.549657 & 7.612189 \\
cpi & 198 & 5.618091 & 5.708266 & 0.448349 & 4.717606 & 6.310282 \\
ppi & 198 & 5.732865 & 5.829974 & 0.517078 & 4.725616 & 6.455199 \\
investment & 180 & 6.128206 & 6.257715 & 0.850368 & 4.200205 & 7.904187 \\
m2 & 198 & 9.255687 & 9.483222 & 1.067872 & 6.994025 & 10.58723 \\
bsccy & 198 & 8.357956 & 8.565993 & 0.844450 & 6.49768 & 9.382839 \\
deposit & 198 & 1.685731 & 1.648659 & 0.266416 & 1.193922 & 2.512035 \\
RTS & 198 & 6.848015 & 7.009036 & 0.641739 & 5.104490 & 7.807868 \\
net export & 198 & 9.148045 & 9.260454 & 0.522486 & 7.705713 & 9.921131 \\
\hline
\end{tabular}


The data were chosen from 2001 to 2017. All the data are in monthly data and taken the natural log.We chose the data of the Russia export oil prices instead of international crude oil price because the Russia exports oil prices can reflect the money that the Russia get from selling the oil.

\subsection{Result}

This table displays ordinary least squares results estimating how ruble varies with oil price. The sample contains all monthly data from January the 2000 to June the 2017. *** denote significance at the $1 \%$ level. All the variable definitions are provided in Table 1.

Dependent variable is Ruble against the dollar.

Table 3: result

\begin{tabular}{llll}
\hline Oil & $-0.364895^{* * *}(-11.32323)$ & investment & $0.015332(1.179553)$ \\
reserve & $-2.38285^{* * *}(-8.79724)$ & M2 & $-0.143832(-1.394762)$ \\
income & $0.70771^{* * *}(2.601775)$ & bsscy & $0.031561(0.388489)$ \\
cpi & $0.437144^{* * *}(3.107355)$ & deposit & $0.102639^{* * *}(4.244853)$ \\
ppi & $0.709401^{* * *}(6.313869)$ & RST & $-0.004077(-0.212021)$ \\
net export & $0.02614(1.039621)$ & & \\
Adjust R_squared & 0.946759 & & \\
\hline
\end{tabular}

From talbe 2 and table 3,we can see that the ruble exchange rate is significantly correlated with oil prices, ppi, cpi, foreign exchange reserve and benchmark one-year deposit rate. Our judgment was confirmed that the high oil price has played an important role in supporting the ruble exchange rate.

In fact, at the end of 20th century, the price of oil was just $\$ 20$ a barrel. But it once rose to $\$ 150$ a barrel. As Russian oil production and export volume maintained at a steady level, its export earnings had a huge increase. In 2000, Russian export earning was 35 billion US dollars and in 2012, it was 269 billion US dollars.

With the help of the rising price of oil, the Russia government reached many economic targets. First, economic growth: before the economic crisis in 2008, the growth rate of Russian GDP kept at $6.5 \%$. Second, the reserve growth: from the initial 15 billion US dollars up to 600 billion US dollars. Third, debt level was controlled. In 2005, it was 20\% of Russian GNP but it dropped to $8 \%$ at an all-time low. All these played a vital role in stabilizing the ruble exchange rate. 


\section{Actions of Russia's government}

\subsection{Using reserves to protect the exchange rate}

On December 25, 2014, Russian finance minister declared that the ruble crisis was over after five consecutive days of steady ruble exchange rates. And the currency also rose from a record low of 80 rubles for 1 dollar to $\$ 1$ convertible 53 rubles.

The stabilization of the ruble, of course, also owe to the Russian government's various actions to adjust the result, in order to avoid a repeat of the 1998 rubles crisis, according to central bank of Russia, so as to support their banking system and prop up the ruble's value, the Russian government and the central bank had spent about \$30 billion of foreign exchange reserves to interfere with the ruble exchange rate in half a month before the Christmas day in 2014.

\subsection{The government cut spending and slashed spending}

In order to relieve the pressure of financial of Russian government, Russian President announced a 10 percent pay cut for the Russian government officials, in a bid to reduce government spending to offset falling revenue.

\subsection{Strengthening control of the economy to boost confidence}

When the ruble was in the doldrums, the Russian government began to tighten controls on all kinds of transactions. In the bank, the Russian central bank has sent a working supervision group to monitor foreign exchange transactions of major Banks to crack down on speculation, and provided foreign currency funds to large domestic Banks, encouraging Banks to lend foreign currency to exporters and control the failing Banks. Second, the Russian State Duma had also passed a resolution to provide 1 trillion rubles to the deposit insurance institutions to boost confidence in the Russian financial sector.

\section{Learning from the ruble crisis}

Since the 1990s, both China and Russia have been in the process of reforming from the planned economic system to the market economy. Both sides have the same economic background and reform demands. Oil, as an important industrial raw material, has an irreplaceable role and status in economic development, and its price fluctuation will be closely related to the economy of a country. And as the Chinese national power grows, the yuan will go out of the country, and it will be a part of China's financial reforms, and the financial markets of China will be more and more connected to the international financial 
markets. It is necessary to learn from Russia's ruble crisis.

\subsection{Economic diversification is the best way to prevent similar risks}

Russia has been hit by the ruble crisis. Despite the western sanctions that have been caused by the Ukraine crisis and the Crimea, it is due to the economic structure of the oil economy. Exports and even the country's fiscal revenues depend heavily on oil prices, and even when Russia is making its annual budget, it is based on the expected oil price, which will expose the country's economy to risk if oil prices fluctuate.

Only by adjusting the economic structure and accelerating industrial optimization and upgrading, can we avoid the emergence of adverse situations that affects the health and stability of the entire economic system because of the sharp fluctuations in prices of some commodity prices.

Although China is not like Russia, it is highly dependent on oil for economic development. However, with the development of China's social economy, the domestic dependence on oil is increasing, and the domestic oil production is far from meeting the demand for oil and other energy sources. Only by establishing oil strategic reserves can we master the initiative when oil prices fluctuate in the future.

\subsection{Attaching great importance to the reform of the order in the process of marketization reform}

In the early 1990s, the development economist McKinnon proposed that these countries should strictly follow the order of reform in the reform process. Russia has opened up its capital markets too quickly, allowing the money to go in and out. So the outbreak of the Russian financial crisis has a very strong link to the impact of international swimming capital. China is currently in the process of economic marketization and financial liberalization. However, the present situation in our domestic, administration of financial and economic intervention still happen. Administrative needs and requirements are still around the allocation of resources. In respect of the financial system, the domestic financial system is still in relatively low-level and immature stage. Therefore, under the background, implementation of capital account opening to the outside world has to be very careful. At the same time, in the process of reform, our country need to slowly but surely, step by step, not covet fast, in a short time. 


\subsection{Reposition the status and the role of China's foreign exchange reserves}

In the financial crisis, to stabilize the ruble, Russia consumed a lot of countries in previous years and accumulated huge foreign exchange reserves, from which we can also see foreign reserves plays a special role for a country's financial stability.

Over the years, many economists also criticized China's foreign exchange reserve scale which is too large and inefficient. The devaluation of the dollar declines in brings down China's foreign exchange reserves value in a matter of fact. However, from this crisis, we can also see the role of foreign exchange reserves. In the reality the voice and the dominant power of the world financial system remain in the hands of western countries, a large foreign exchange reserve is an important guarantee to protect the national economy from external invasion and to maintain stability.

\section{References}

1. Li jianming, Cause and impact of the Russia Ruble crash and opportunities for cooperation between China and Russian, Comparative Economic \& Social Systems (2015) 46-57.

2. Sujunhe, The influence, trend and countermeasures of international oil price fluctuation, Macroeconomic Management (2015) 58-60.

3. Wang nan, Zhang xiaotong, A Cointegration Analysis on RMB Exchange Rate and International Oil Price, Northeast Asia Forum (2009) 9-15. 